Vol IV. No.1, September 2019, hlm. 12 - 22

Available online at www.jurnal.una.ac.id/indeks/jmp

\title{
ANALISIS KESALAHAN SISWA DALAM MENYELESAIKAN SOAL MATEMATIKA BERDASARKAN KRITERIA WATSON
}

\author{
Sarwoedi \\ Mahasiswa Pascasarjana S2 Pendidikan Matematika Universitas Bengkulu \\ Email: sarwoedilisma@gmail.com
}

\begin{abstract}
Abstrak
Tujuan penelitian ini adalah mengetahui dan mengidentifikasi jenis-jenis kesalahan yang dilakukan siswa dalam mengerjakan soal matematika dengan kriteria Watson dan mengetahui jenis kesalahan apa yang sering dilakukan siswa. Penelitian ini merupakan penelitian kuantitatif deskriptif dengan metode survei. Dari 184 Orang siswa kelas XII dipilih satu kelas yang mengikuti kegiatan Jam Tambahan atau Les untuk menghadapi Ujian Nasional Tahun 2019.Hasil penelitian menunjukan bahwa ada 2 jenis kategori kesalahan yang sama dan terbanyak pada sekolah SMA negeri 10 Rejang Lebong yang dilakukan siswa yaitu kesalahan tipe rlc (mengerjakan tanpa konsep atau menjawab langsung tanpa cara) dan ao (selain ketujuh kategori). Dan yang menjadi penyebab terdinya kesalahan dalam menyelesaikan soal cerita tersebut dikarena siswa tidak memahami konsep yang diinginkan dari soal jadi mereka menyelesaikannya dengan prosedur yang tidak tidak tepat.
\end{abstract}

Kata Kunci: Matematika, Kesalahan Siswa, Kriteria Watson

\begin{abstract}
The purpose of this study is to identify and identify the types of errors made by students in working on mathematical problems with Watson's criteria and find out what types of mistakes students often make. This research is a descriptive quantitative research with survey method. Of 184 class XII students, one class was selected to take part in the Additional Hours or Tutoring activities to face the 2019 National Examination. The results of the study showed that there were 2 types of the same category of errors and the most in the 10 Rejang Lebong state high school students made by students namely the type of rlc (working without concepts or answering directly without means) and $\mathrm{AO}$ (other than the seven categories). And the cause of error in completing the problem of the story is because students do not understand the desired concept of the problem so they solve it with incorrect procedures.
\end{abstract}

Keywords: Mathematics, Student Mistakes, Watson Criteria 
Vol IV. No.1, September 2019, hlm. 12 - 22

Available online at www.jurnal.una.ac.id/indeks/jmp

\section{PENDAHULUAN}

Ilmu adalah pengetahuan tentang suatu bidang yang disusun secara bersistem menurut metode tertentu, yang dapat digunakan untuk menerangkan gejala tertentu di bidang (pengetahuan) itu (Anonim, 2018). Ilmu sangatlah berpengaruh terhadap kehidupan kita, dengan ilmu terciptalah benda-benda yang dapat mempermudah pekerjaan kita, dengan ilmu kita dapat mengelola sumber daya alam yang ada disekitar, dengan ilmu pula kita beramal. Matematika merupakan salah satu ilmu yang penting untuk dipelajari, karena matematika merupakan pilar utama dari ilmu pengetahuan. Perkembangan ilmu pengetahuan dipengaruhi matematika. Matematika mengajarkan bagaimana cara berpikir secara logis, tersusun rapi dengan menggunakan konsep yang ada. Hal yang dibutuhkan dalam keseharian, yang perlunya menentukan langkah-langkah secara baik dan tersusun rapi. Dari matematika yang telah diajarkan sangatlah penting juga untuk mengevaluasi apa saja yang sudah dapat dicapai dan apa yang masih menjadi kendala atau kesulitan dalam mempelajari atau menyelesaikan persoalan matematika, salah satunya adalah dalam menyelesaikan soal cerita.

Soal cerita mempunyai beberapa kelebihan selain biasanya soal cerita menceritakan kasus keseharian yang dekat dengan keseharian sekitar, soal cerita juga membutuhkan pemahaman bahasa yang baik sehingga dapat mengubahnya kedalam bentuk operasi matematikanya, bisa juga melihat bagaimana cara berfikir siswa dalam mengerjakannya, dibandingkan dengan siswa langsung diberikan dalam bentuk operasi matematika.

Keterampilan menyelesaikan soal cerita juga memegang peran penting dalam jangka panjang karena aplikasi matematika di bidang lain selalu berkaitan dengan pembuatan model matematika. Seperti yang dikatakan oleh Davis dan Mc Killip (Budiono:2008) "Walaupun keterampilan menyelesaikan soal cerita memegang peran penting dalam jangka panjang, tetapi soal cerita bukan hal yang mudah bagisiswa untuk mengerjakannya dan juga bukan hal mudah bagi guru untuk

mengajarkannya."(Budiyono,2008)

"Soal cerita biasanya

diwujudkan dalam kalimat yang

di

dalamnyatersembunyi persoalan atau permasalahan yang penyelesaiannya menggunakan keterampilan berhitung. Dengan demikian, dilihat dari bentuknya, soal cerita biasanya berbentuk tes uraian. Jika dikaitkan dengan taksonomi Bloom, soal cerita yang berbentuk uraian tersebut berada pada ranah aplikasi. Pada tahap-tahap tertentu, soal cerita yang berbentuk uraian dapat dikategorikan ke dalam ranah sintesis dan analisis."

Menurut Lia (Asmita Ratih Wibowo: 2013) "Soal cerita dalam matematika adalah soal yang disajikan dalam bentuk kalimat sehari-hari dan umumnya merupakan aplikasi dari konsep matematika yang dipelajari." 
Vol IV. No.1, September 2019, hlm. 12 - 22

Available online at www.jurnal.una.ac.id/indeks/jmp

Soal cerita mempunyai karakteristik sebagai berikut:

1. Soal dalam bentuk ini merupakan suatu uraian yang memuat beberapa konsep matematika sehingga siswa ditugaskan untuk merinci konsep-konsep yang terkandung dalam soal tersebut.

2. Umumnya uraian soal merupakan aplikasi konsep matematika dalam kehidupan sehari-hari/ keadaan nyata/real world, sehingga siswa seakanakan menghadapi kenyataan yang sebenarnya.

3. Siswa dituntut menguasai materi tes dan bisa mengungkapkannya dalam bahasa tulisan yang baik dan benar.

4. Baik untuk menarik hubungan antara pengetahuan yang telah dimiliki siswa dengan materi yang sedang dipikirkannya.

Soal cerita mempunyai beberapa kelebihan selain biasanya soal cerita menceritakan kasus keseharian yang dekat dengan keseharian sekitar, soal cerita juga membutuhkan pemahaman bahasa yang baik sehingga dapat mengubahnya kedalam bentuk operasi matematikanya, bisa juga melihat bagaimana cara berfikir siswa dalam mengerjakannya, dibandingkan dengan siswa langsung diberikan dalam bentuk operasi matematika.

Pengalaman peneliti selama mengajar di SMA Negeri 10 Rejang Lebong dan sekarang, sebagian besar siswa mendapatkan nilai matematika yang kurang dari pelajaran lain terutama jika dibandingkan dengan pelajaran UN yaitu IPA, Bahasa Indonesia danlainnya. Siswa juga jika diberikan soal cerita terlihat merasa kesulitan dalam mengerjakannya. Misalkan jika dalam operasi bilangan bulat siswa diberikan soal 4 x 15: 6 akan lebih mudah jika dibandingkan dengan soalnya dalam bentuk cerita menjadi "Toni membeli 4 kotak pensil, yang setiap pensil berisi 15 buah pensil. Kemudian diberikan kepada 6 orang temannya sama rata, berapa pensil yang di dapatkan teman toni?", Bisa saja siswa mengerjakannya $4+15-6$ dll. Sehingga hasilnya pun menjadi tidak tepat.

Hasil evaluasi belajar siswa merupakan salah satu cara untuk dapat mengetahui sejauh mana perkembangan siswa dan tercapainya tujuan belajar terutama dalam pelajaran matematika yang masih dirasa sulit bagi siswa dibandingkan materi yang lainnya. Sehingga peneliti merasa penting untuk menindaklanjuti evaluasi hasil belajar siswa dengan harapan dengan menganalisis hasil belajar siswa dapat diketahui kesulitan yang siswa alami dan pendidik dapat menentukan langkah perbaikan.

Hasil wawancara dengan Ibu Yuniar Tri Kartikatika, S.Pd dan Burhannudin, S.Pd guru Matematika pada kelas XII SMAN 10 Rejang Lebong (Senin, 11 September 2018), menuturkan bahwa masih terdapat siswa kelas XII IPA 1 yang mengalami kesulitan belajar matematika. Ibu Ira Rahmawati juga menambahkan bahwa terdapat beberapa siswa yang sulit dalam 
Vol IV. No.1, September 2019, hlm. 12 - 22

Available online at www.jurnal.una.ac.id/indeks/jmp

memahami materi mata pelajaran matematika yang diajarkan. Hal ini ditandai dengan adanya pengulangan-pengulangan dalam menjelaskan materi baru siswa mampu memahami materi yang disampaikan. Hal ini juga dapat dilihat dari rendahnya hasil belajar pada mata pelajaran matematika yang diperoleh siswa.

Kesalahan

dalam

menyelesaikan soal tentu tidak hanya dilakukan oleh siswa yang nilai ujiannya termasuk dalam kelompok rendah saja, siswa yang nilai ujiannya termasuk dalam kelompok sedang dan kelompok tinggi juga melakukan kesalahan. Deskripsi kesalahan dari masing-masing kelompok siswa tersebut perlu diketahui agarselanjutnya dapatdiketahui kecenderungan dari kesalahan yang dilakukan siswa kelompok tinggi, kelompok sedang, maupun kelompok rendah, sehingga nantinya dapat dijadikan sebagai bahan pertimbangan guru dalam menentukan kesalahan manayangperluuntuksegeradiatasi.

Menurut Watson (Moh. Asikin:2003) terdapat 8 klasifikasi atau kriteria kesalahan dalam mengerjakan soal yaitu"(i) data tidak tepat (innappropriate data) disingkat id, (ii) prosedur tidak tepat (inappropriate procedure) disingkat ip, (iii) data hilang (ommited data) disingkatod,(iv) kesimpulan hilang (omitted conclusion) disingkatoc, (v) konflik level respon (response level conflict) disingkatrlc, (vi) manipulasi tidak langsung (undirected manipulation) disingkatum, (vii) masalah hirarki keterampilan (skillshierarchy problem) disingkatshp,dan (viii) selain ke-7 kategori di atas (above other) disingkatao.

Kriteria pertama yaitu data tidak tepat(innappropriate data), di manakesalahan siswa meliputi penggunaan data yang kurang tepat dengan kata lain salah dalam memasukan nilai ke variabel. Misalnya dalam soal lingkaran, nilai yang seharusnya dimasukan adalah nilai jari-jari, tetapi siswa memasukan nilai diameter, atau sebaliknya. Kriteria kedua yaitu prosedur tidak tepat (inappropriate procedure), dalam kesalahan prosedur ini dapat berupa siswa salah dalam menentukan rumus yang dipakai, misalnya dalam menentukan volume bola, tetapi rumus yang dipakaikan adalah rumus menentukan luas lingkaran, yang seharusnya menjadi. Ataupun ada siswa yang salah dalam menjumlahkan atau mengurangkan atau mengalikan atau juga membagikan bilangan. Siswa juga salah dalam memberi tanda misalnya yang seharusnya tanda jumlah, yang ditulis kurang, kali atau bagi, begitu juga sebaliknya.

Kriteria ketiga yaitu data hilang(ommited data), dalam data hilang inisudah jelas berarti saat mengerjakannya ada data yang tidak memang hilang yang seharusnya ada menjadi tidak ada. Kriteria keempat yaitu kesimpulan hilang (omitted conclusion), dalam kesimpulan hilang berarti dalam menyelesaikan soal siswa belum sampai tahap akhir dari apa yang soal minta.

Kriteria kelima yaitu konflik
level respon(response level conflict).Dalam konflik respon ini siswa terlihat kurang memahami bentuk soal, sehingga yang dilakukan 
Vol IV. No.1, September 2019, hlm. 12 - 22

Available online at www.jurnal.una.ac.id/indeks/jmp

adalah melakukan operasi sederhana dengan data yang ada yang kemudian dijadikan hasil akhir dengan cara yang tidak sesuai dengan konsep yang sebenarnya, ataupun siswa hanya langsung menuliskan jawabannya saja tanpa ada alasan atau cara yang logis.

Kriteria keenam yaitu manipulasi tidak langsung (undirected manipulation). Dalam manipulasi tidak langsung ini ada penyelesaianproses merubah dari tahap yang satu ke tahap selanjutnya terdapat halyang tidak logis, misalnya $\frac{22}{7} \cdot 44=44 \cdot \frac{7}{22}$. Contoh lainnya saat operasi bilangan bulat $34-4 \times 5=20-34$. Ada perpindahan/perubahan sehingga operasi tersebut menjadi kurang tepat karena tidak logis dalan melakukannya.

Kriteria ketujuh yaitu masalah hirarki keterampilan (skills hierarchyproblem ). Dalam masalah hirarki keterampilan ini berkaitan denganbagaimana siswa dapat merubah rumus dasar menjadi rumus yang diminta, misalnya dalam mencari panjang suatu balok, rumus dasarnya $\mathrm{V}=\mathrm{p} \times 1 \times \mathrm{t}$ menjadi $\mathrm{p}=\mathrm{V}$ : $(\mathrm{p} \times \mathrm{t})$ dan juga kreatifitas siswa dalam merubah bentuk-bentuk aljabar dan lain sebagainya yang membutuhkan keterampilan merubah susunan. Terakhir kriteria kedelapan adalah selain ketujuh kategori di atas (above other), salah satunya yaitu tidak mengerjakan soal (Muhammad, 2003).

Dari hasil test yang dilakukan akan terlihat jenis kesalahan mana paling banyak dilakukan oleh siswa, ini sebagai bentuk evaluasi dalam proses belajar sehingga bisa menjadi lebih baik.

\section{METODE}

Dalam penelitian ini merupakan penelitian kuantitatif deskriptif. "Penelitian deskriptif adalah penelitian yang dilakukan untuk menggambarkan atau menjelaskan secara sistematis, faktual dan akurat mengenai fakta dan sifat populasi tertentu, tidak untuk mencari ataupun menerangkan keterkaitan antar variabel (Sugiyono, 2013).Sampel yang digunakan dalam penelitian ini adalah 34 siswa dari kelas XII IPA 2.

Instrumen yang yang digunakan dalam penelitian ini adalah soal-soal tes uraian atau soal cerita sebanyak 5 soal dan dikerjakan dalam wakti 60 menit. Siswa mengerjakan dalam bentuk uraian Soal-soal yang diambil adalah soal-soal UN dari 5 tahun terakhir yang kemudian peneliti pilih sebagai soal-soal yang akan dipakai untuk penelitian sebagai bahan analisis. Tidak semua materi UN dijadikan referensi soal, alasannya karena tidak semua materi memiliki soal cerita yang dikerjakan dengan uraian semisal pencerminan, sitem kordinat dan lainya, sehingga hanya materi tertentu saja yang dapat diambil seperti aljabar, bangun datar, bangun ruang, dan sebagainya.

Pada hasil tes tertulis, data yang dikumpulkan adalah kesalahankesalahan siswa dalam menyelesaikan soal-soal. Analisis yang digunakandalam penelitian ini adalah menggunakan data kuantitatif statistik deskriptif. Statistik deskriptif adalah statistik yang digunakan 
Vol IV. No.1, September 2019, hlm. 12 - 22

Available online at www.jurnal.una.ac.id/indeks/jmp

untuk menganalisis data dengan cara mendeskripsikan atau menggambarkan data yang telah terkumpul sebagaimana adanya tanpa bermaksud membuat kesimpulan yang berlaku umum atau generalisasi.

\section{HASIL DAN PEMBAHASAN}

Berdasarkan hasil pekerjaan siswa dalam mengerjakan soaltes yang diberikan, didapatkan:

\section{Soal No 1 Tentang Sistem}

Persamaan Linier Dua Variabel

Lima Tahun Lalu umur Ali sama dengan 4 kali umur Yudi. Empat tahun yang akan datang, dua kali umur Ali sama dengan 3 kali umur Yudi ditambah 1 tahun. Jumlah umur Ali dan Yudi saat ini adalah?

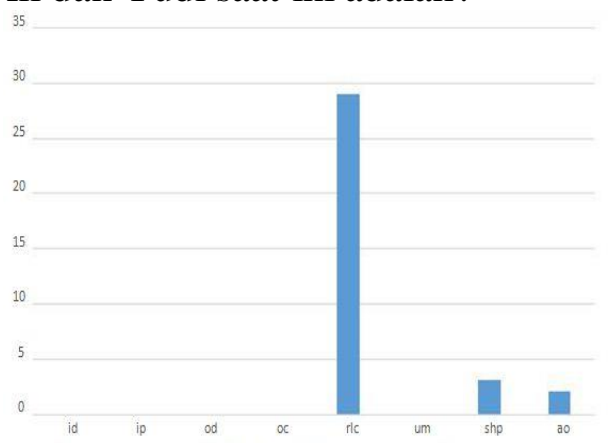

Gambar 1. Analisis Soal No.1

\section{Analisis Soal :}

Berdasarkan gambar 1 . terlihat bahwa hampir seluruh siswa (29 dari 34 siswa) tidak memahami konsep soal. Sebagian besar siswa mengerjakan dengan cara yang sangat sederhana dengan menggunakan data yang ada kemudian dijumlah, dikurang, dibagi, atau dikali. Siswa belum mengerti bahwa dalam soal ini perlu menggunakan konsep sistem persamaan linier. Seperti yang dilakukan Rahmat Apthree, Vivi agustina dan Tomi Berlian, mereka sudah memahami bahwa soal ini merupakan konsep sitem persamaan linier. Akan tetapi pada pengerjaannya mereka langsung mengalikan umur Yudi dan Umur Ali. Sehingga mereka mendapatkan jawaban yang kurang tepat.

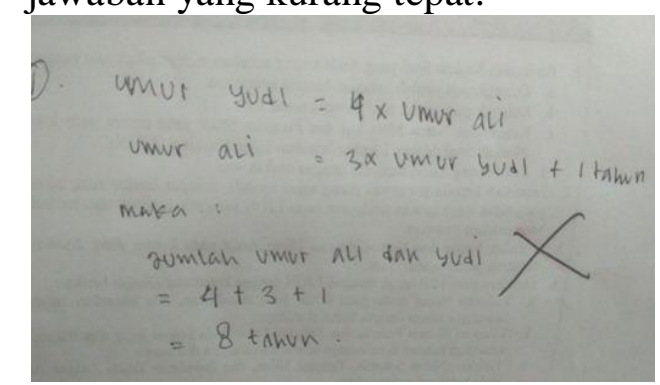

Gambar 2. Contoh Pengerjaan Soal 1

\section{Soal 2 TentangSistem Persamaan} Linier dua Variabel

Harga $2 \mathrm{~kg}$ apel dan $6 \mathrm{~kg}$ melon Rp 46.000,00, sedangkan harga $4 \mathrm{~kg}$ apel dan $3 \mathrm{~kg}$ melon Rp 47.000,00. Berapakah harga untuk $5 \mathrm{~kg}$ apel dan $3 \mathrm{~kg}$ melon?

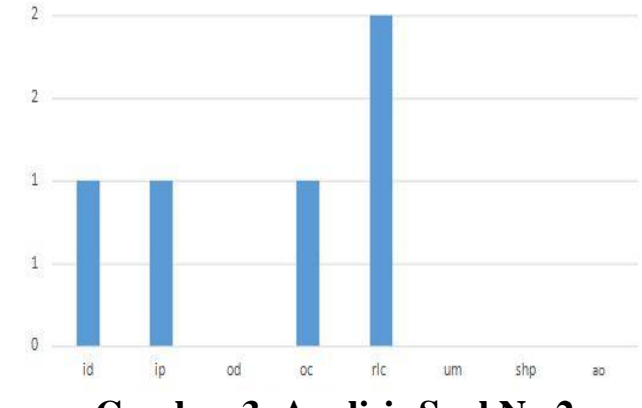

Gambar 3. Analisis Soal No.2

\section{Analisis Soal}

Berdasarkan analisis gambar 3. soal nomor 2 terlihat pula bahwa hampir seluruh siswa sudah menguasai materi dengan baik, hanya 4 siswa yang masih masih melakukan kesalahan dan 2 diantaranya yaitu Feri dan Syahrul ananta yang masih belum mengerti tentang konsep yang dipakai dalam 
Vol IV. No.1, September 2019, hlm. 12 - 22

Available online at www.jurnal.una.ac.id/indeks/jmp

soal ini. Menggunakan data yang ada, kemudian dioperasikan matematik untuk menemukan jawaban. Sedangkan Lisa Herlina sudah paham tetang materi ini, tetapi masih salah dalam operasi perkalian pada persamaan pertama saat mencari nilai $\mathrm{Y}$ dimana $46.000 \times 2=$ 82.000 , hasil yang benar adalah 92.000 dan juga untuk persamaan keduajumlah apelnya masih $2 \mathrm{~kg}$ sama seperti persamaan pertama, yang seharusnya adalah 4 $\mathrm{Kg}$,sehingga Rizqon melakukan kesalahan id dan ip. Untuk Izzaldin, melakukan kesalahan $o c$, karena sudah menemukan harga Apel dan melon tinggal memasukkan ke persamaan saja.

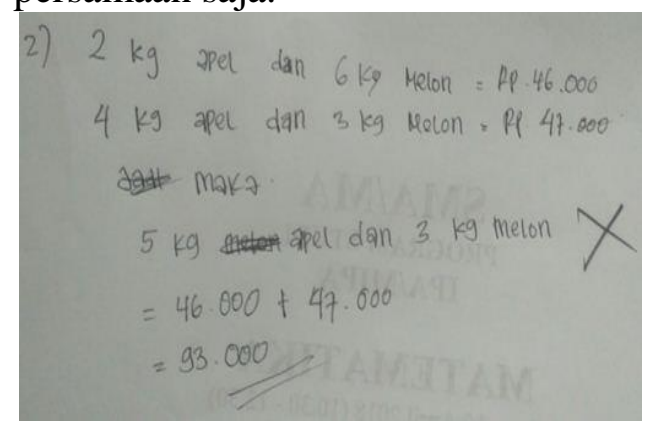

Gambar 4. Contoh Pengerjaan Soal 2

\section{Soal 3 TentangProgram Linier}

Seorang pedagang kue akan membuat dua jenis kue, setiap kue A menggunakan modal Rp. 2.000,00 dan dijual memperoleh keuntungan Rp. 1.000,00 per buah, sedang untuk kue B menggunakan modal Rp. $3.000,00$ dan dijual memperoleh keuntungan Rp. 1.500,00 per buah. Modal yang disediakan adalah Rp.1.200.000,00 dan kue dibuat paling banyak 500 buah per hari. Jika kue terjual habis tentukan keuntungan maksimum yang diperoleh pedagang kue tersebut adalah....

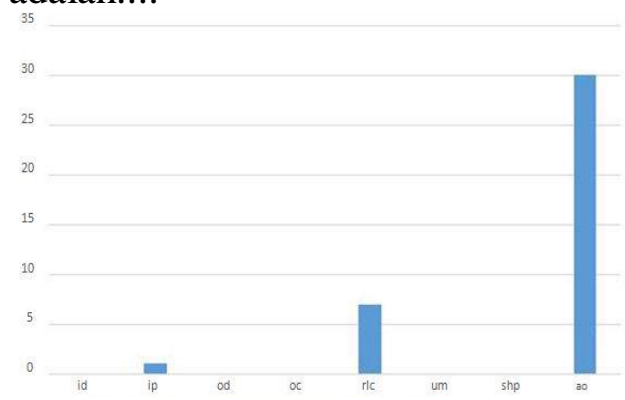

Gambar 5. Analisis Soal No.3

\section{Analisis Soal :}

Analisis dalam soal nomer 3 pada gambar 5, hampir seluruh siswa tidak menjawab soal ini, ada kemungkinan mereka tidak cukup waktu mengerjakannya karena soal ini diangkap sulit dan berbelit sehingga diakhirkan dan kehabisan waktu. Terdapat 6 orang yang mengerjakan dengan mengarang tanpa menggunakan konsep yang seharusnya dipakai, dalam hal ini adalah system persamaan linier dua variabel. Hanya satu yaitu Windi Velinca yang sudah tepat dalam mengunakan konsep yang menunjukan ia paham, tetapi dalam prosedurnya terdapat kesalahan yaitu pada saat harus mengeliminasi menghilangkan salah satu variabel, jika tandanya sama yang seharusnya dilakukan adalah pengurangan, sedangkan Deva melakukan hal sebaliknya yaitu penjumlahan, walaupun ketemu jawabannya, tetapi menjadi kurang tepat.

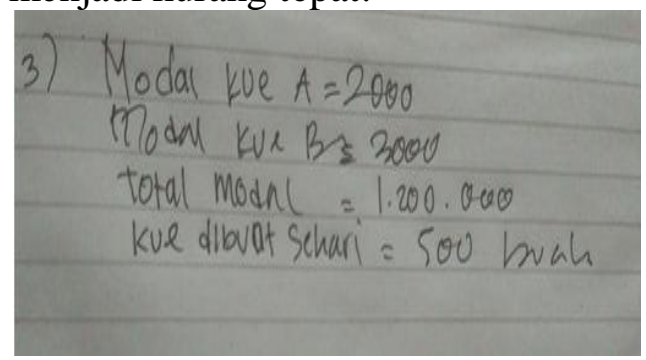

Gambar 6. Contoh Pengerjaan Soal 3 
Vol IV. No.1, September 2019, hlm. 12 - 22

Available online at www.jurnal.una.ac.id/indeks/jmp

\section{Soal 4 Tentang Deret Aritmetika}

Tempat duduk gedung pertunjukkan film diatur mulai dari baris depan ke belakang dengan banyak baris di belakang lebih 4 kursi dari baris didepannya. Bila dalam gedung pertunjukan terdapat 15 baris kursi dan baris terdepan ada 20 kursi. Kapasitas gedung pertujukan tersebut adalah?

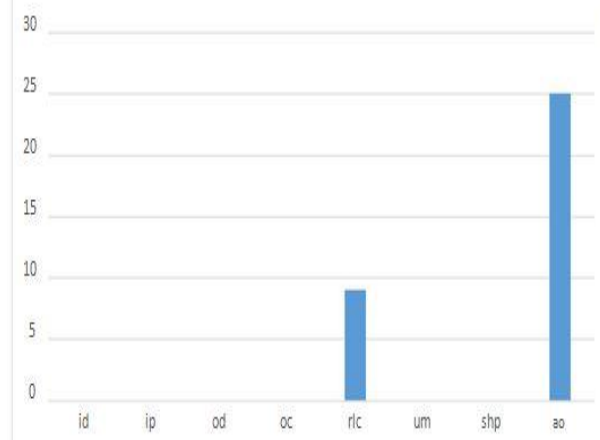

Gambar 7. Analisis Soal No.4

\section{Analisis Soal :}

Berdasarkan dari gambar 7. terlihat sebagian besar siswa tidak selesai mengerjakan terlihat dari banyaknya $a o$, walaupun waktu 60 menit merupakan waktu yang sangat cukup untuk mengerjakan 5 soal ini dengan cara uraian. Untuk siswa yang masih berusaha mengerjakan, siswa pun belum mengerti tentang maksud dari soal, terlihat dari jenis kesalahan yang dilakukan adalah $r l c$, siswa mengerjakan dengan sangat sederhana. Ada yang mengalikan secara langsung dari keterangan yang mereka dapat di soal.

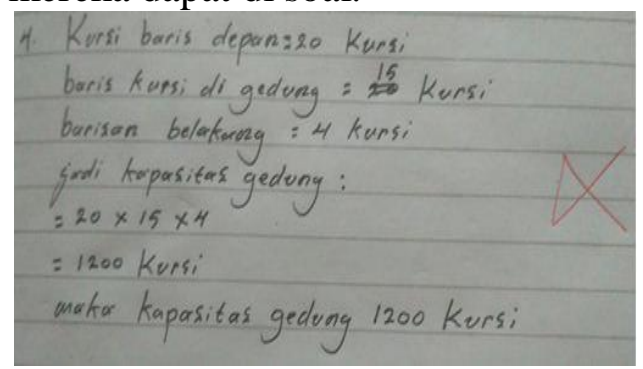

Gambar 8. Contoh Pengerjaan Soal 4

\section{Soal 5 Tentang Kombinasi}

Pada suatu tes penerimaan pegawai, seorang pelamar wajib mengerjakan 6 soal diantara 14 soal. Soal nomor 1 sampai 3 harus dikerjakan. Banyak pilihan soal yang dapat dilakukan adalah?

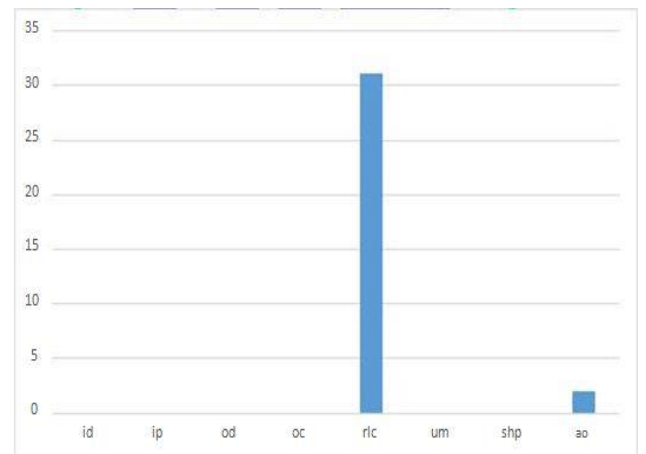

Gambar 9. Analisis Soal No.5

Analisis Soal

Berdasarkan gambar 9 . terlihat bahwa siswa tidak memahami konsep himpunan. Di mana beberapa siswa langsung menjawab dan beberapa hanya melakukan operasi matematika tanpa menggunakan konsep kombinasi. Ada siswa sudah paham membuat konsep kombinasi untuk membantu dalam mengerjakan, akan tetapi tidak sedikit siswa yang salah meletakan. 3 soal yang harus dikerjakan tidak mereka lihat sehingga mereka langsung membuat kombinasi ${ }_{14} \mathrm{C}_{6}$, sehingga mereka mendapatkan jawaban yang kurang tepat. Seharusnya siswa mencari terlebih dahulu jumlah soal yang harus dikerjakan yang selanjutnya barulah mengurangi dengan banyaknya soal untuk diselesaikan sehingga ketemulah jawaban banyaknya pilihan soal yang akan dikerjakan. Hanya satu siswa yang bias menyelesaikan soal ini yaitu Sulis. 
Vol IV. No.1, September 2019, hlm. 12 - 22

Available online at www.jurnal.una.ac.id/indeks/jmp

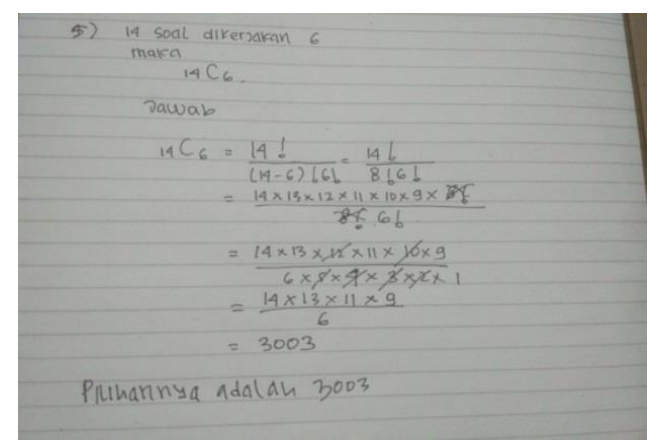

Gambar 10.Contoh Pengerjaan Soal 5

\section{Pembahasan}

Pada soal 1 terlihat bahwa kesalahan $r l c$ merupakan kesalahan terbanyak yang dilakukan oleh siswa dibandingkan dengan kesalahan yang lain.Sedangkan di soal no 2 kesalahan siswa lebih banyak pada rlc yaitu sebesar $9,52 \%$, sedangkan yang lain merata pada kesalahan $i d$, $i p$, dan $o c$.Pada soal 3 tentang system persamaan linier dua variabel. Kesalahan siswa terbanyak yaitu pada kesalahan ao, dengan presentase cukup besar yaitu persentase 78,95\%. Memungkinkan bawah soal ini masih belum dipahami oleh siswa.Pada soal 4tentang deret aritmatika kesalahan pengerjaan soal yaitu pada kriteria $a o$ yang dimana siswa tidak mengerjakan soal ini baik belum mengerti ataupun waktunya yang kurang untuk mengerjakan dengan persentasi yaitu 73,53\%. Kesalahan yang cukup besar juga terjadi pada kriteria $r l c$, walaupun anak menjawab tetapi jawabannya tidak menggunakan konsep yang seharusnya dipakai, dengan persentase yaitu $26,47 \%$.Pada soal 5 tentang kombinasi kesalahan siswa tersebut terdapat pada kesalahan $r l c$, dimana presentasenya yaitu $91,18 \%$, ini tetap menunjukan bahwa siswa kelas XII IPA 2 memiliki masalah menyelesaikan soal cerita tentang kombinasi.

Secara keseluruhan ada 3 jenis kesalahan yang dominan dilakukan, yaitu jenis kesalahan ip dimana siswa melakukan prosedur yang tidak tepat, selanjutnya yaitu siswa banyak melakukan kesalahan tipe ao di mana siswa tidak mengerjakan soal tersebut ataupun melakukan kesalahn lain selain ketujuh kategori, dan yang paling banyak dilakukan siswa adalah kesalahan jenis $r l c$ di mana siswa tidak memahami maksud soal sehingga yang dilakukan hanya operasi sederhana tanpa menggunakan konsep yang seharusnya dilakukan. Jika dilihat dari ketiga kesalahn terbesar yang dilakukan siswa ini terlihat siswa belum menguasai sepenuhnya materi yang diajarkan oleh guru.

Berdasarkan hasil wawancara dengan 5 siswa, yang menjadi penyebab terdinya kesalahan dalam menyelesaikan soal cerita tersebut dikarena siswa tidak memahami konsep yang diinginkan dari soal jadi mereka menyelesaikannya dengan prosedur yang tidak tidak tepat.

Hal ini sejalan dengan penelitian Miskatun Nuroniah, mahasiswa UNNES, 2013. Berdasarkan hasil penelitian dan pembahasan dapatdisimpulkan jenis kesalahan yang paling menonjol adalah data tidak tepat (id), prosedur tidak tepat (ip), kesalahan hierarki keterampilan (shp). Kesalahan tersebut disebabkan karena beberapa hal diantaranya yaitu peserta didik tidak memahami konsep pada lingkaran, peserta didik tidak memiliki keterampilan menyelesaikan masalah matematika, 
Vol IV. No.1, September 2019, hlm. 12 - 22

Available online at www.jurnal.una.ac.id/indeks/jmp

dan peserta didik tidak memiliki keterampilan manipulasi numerik dan operasi hitung. Sedangkan dari hasil perhitungan nilai rata-rata untuk soal pemecahan masalah level multistruktural sebesar 32.67, relasional 32.33, dan abstrak diperluas 37.33. dari hasil tersebut menunjukan kemampuan pemecahan masalah peserta didik masih rendah (Husnul, 2012).

Sejalan juga dengan hasil henelitian Husnul Istipham, mahasiswa IAIN Mataram, 2012 dengan judul : "Identifikasi Kesalahan Siswa dalam Menyelesaikan Soal-Soal ProgramLinier Pada Siswa Kelas XII IPA MAN Gerung Tahun Pelajaran 2011/2012". Berdasarkan hasil penelitian dan pembahasan didapat bahwasecara umum letak kesalahan siswa dalam menyelesaikan soal program linier ada pada penggunaan data yang tidak tepat (id), siswa tidak dapat melanjutkan penyelesaian soal (shp), prosedur yang digunakan tidak tepat (ip), siswa tidak merespon sesuai data yang diberikan (ao), dan siswa gagal dalam menyimpulkan (oc). Selain itu beberapa siswa belum paham dalam menyelesaikan soal cerita, dalam hal ini siswa kesulitan dalam menenukan Selain itu beberapa siswa belum paham dalam menyelesaikan soal cerita, dalam hal ini siswa kesulitan dalam menenukan metode yang akan digunakan untuk menyelesaikan soal program linier, hal ini terjadi karena siswa kurang paham mengenai konsep program linier dan penyelesaian soal program linier (miskatun, 2013).

\section{SIMPULAN}

\section{a. Kesimpulan}

Jika dilihat dari jumlah keseluruhan, kesalahan terbanyak yang dilakukan siswa di sekolah SMA Negeri adalah kesalahan tipe $r l c$, ao, dan ip. Di mana selama peneliti menganalisis jawaban yang siswa buat, kedua tipe kesalahan rlc dan ao ini yang menutunkan nilai siswa. Sehingga ini perlu diantisipasi guru yang menandakan kemungkinan mereka belum mengerti materi yang disampaikan untuk kesalahan tipe ip ini memang bermacam-macam, tetapi yang menjadi masalah jika kesalahan siswa adalah salah menentukan rumus yang harus dipakai yang seperti ini juga menunjukan bahwa siswa belum paham maksud dari soal. Sedangkan tipe kesalahan shp ini siswa butuh latihan dalam memanipulasi sebuah rumus ataupun aljabar, sehingga jika bertemu soal yang mirip siswa sudah bias melakukan manipulasi yang logis yang biasa dilakukan.Dari kedelapan tipe kesalahan, kesalahan yang belum terjadi adalah kesalahan tipe $o d$ atau kehilangan data.

$$
\begin{array}{ccc}
\text { Dan yang menjadi penyebab } \\
\text { terdinya } & \text { kesalahan dalam }
\end{array}
$$
menyelesaikan soal cerita tersebut dikarena siswa tidak memahami konsep yang diinginkan dari soal jadi mereka menyelesaikannya dengan prosedur yang tidak tidak tepat.

\section{b. Saran}

Untuk penelitian selanjutnya sebaiknya ada tambahan wawancara dalam penelitian seperti ini, supaya lebih mendalam penelitiannya seperti mengetahui kesalahan tipe ip yang 
Vol IV. No.1, September 2019, hlm. 12 - 22

Available online at www.jurnal.una.ac.id/indeks/jmp

siswa lakukan ataupun tipe ao yang cukup menjadi kesalahan dominan

\section{DAFTAR RUJUKAN}

Asmita Ratih Wibowo, Pengaruh Metode Role Play Terhadap KemampuanMenyelesaikan Soal Cerita, UIN Jakarta;2013 Budiyono, Kesalahan Mengerjakan Soal Cerita Dalam Pembelajaran Matematika, Paedagogia (jurnal penelitian pendidikan) Vol.11 Solo, 2008.

http://kbbi.web.id/ilmu, di akses tanggal 15 oktober 2018.

Husnul Istipham, Identifikasi Kesalahan Siswa dalam Menyelesaikan SoalSoalProgram Linier pada Siswa Kelas XII IPA MAN Gerung Tahun Pelajaran 2011/2012. IAIN Mataran:2012

Miskatun Nuroniah, Analisis Kesalahan Peserta Didik

Kelas VIII SMP IT BinaAmal dalam Menyelesaikan Soal Pemecahan Masalah Matematika Pada Materi Pokok Lingkaran. UNNES:2013

Mohammad Asikin, Pengembangan Item Tes dan InterPretasi Respon Mahasiswadalam Pembelajaran Geometri Analit Berpadu Pada Taksonomi Solo. Jurnal Pendidikan dan Pengajaran IKIP Negeri Singaraja, No. 4 TH. XXXVI Oktober 2003

Sugiyono, Metode Penelitian Manajement, (Bandung: Alfabeta, 2013)

Wana Sanjaya, Penelitian Pendidikan : Jenis, Metode, dan Prosedur, (Jakarta:Kencana, 2013) 